\title{
Pentingnya Transparansi Laporan Keuangan terhadap Kinerja Individu
}

\author{
${ }^{1}$ Jenyssa Faizah Farouk \\ ${ }^{1}$ Prodi Administrasi Bisnis Sektor Publik , Politeknik STIA LAN Bandung; jenyssafaizah62@gmail.com
}

Received 06 Juli 2021| Revised 10 Agustus 2021 | Accepted 28 September 2021

*Korespondensi Penulis

\begin{abstract}
Abstrak
Tujuan dilakukannya penelitian ini adalah untuk mengetahui pentingnya transparansi laporan keuangan terhadap kinerja individu. Metode penelitian yang digunakan pada jurnal ini adalah metode kuantitatif dengan sampel yang diambil yaitu sebanyak 23 responden.Teknik pengumpulan data yang digunakan adalah dengan mengisi kuisioner yang dilakukan oleh responden. Hasil penelitian ini menunjukkan bahwa transparansi laporan keuangan yang dilakukan oleh perusahaan akan mempengaruhi kinerja setiap individu yang bekerja pada perusahaan tersebut. Karena dengan mengetahui laporan keuangan yang ada maka para responden berpendapat bahwa para pekerja pada perusahaan tersebut akan tahu apa yang akan mereka lakukan setelah hasil yang mereka dapat, yaitu dengan meningkatkan kinerja mereka ataupun dengan menstabilkan kinerja yang sudah mereka kerahkan.
\end{abstract}

Kata Kunci: Transparansi; Kinerja; Laporan Keuangan.

\begin{abstract}
The purpose of this study is to determine the importance of financial statement transparency on individual performance. The research method used in this journal is a quantitative method with a sample of 23 respondents. The data collection technique used is to fill out a questionnaire conducted by the respondent. The results of this study indicate that the transparency of financial statements made by the company will affect the performance of each individual who works for the company. Because by knowing the existing financial statements, the respondents think that the workers at the company will know what they will do after the results they get, namely by improving their performance or by stabilizing the performance they have mobilized.
\end{abstract}

Keywords: Transparency; Performance; Financial Reports.

\section{PENDAHULUAN}

Beberapa hal yang harus diperhatikan di dalam dunia kerja serta diterapkan untuk mewujudnya cita cita dan tujuan pada tempat bekerja tersebut. Salah satu dari beberapa hal itu adalah kerja sama. Kerjasama adalah suatu bentuk proses sosial, dimana didalamnya terdapat aktivitas tertentu yang ditunjukkan untuk mencapai tujuan bersama dengan saling membantu dan saling memahami aktivitas masing-masing (Abdulsyani : 1994). Selain dengan saling membantu dan saling memahami, dalam bekerja sama juga dibutuhkan sikap saling percaya antara satu pihak dengan pihak lainnya. Untuk memiliki sikap saling percaya itu kita perlu untuk bersikap terbuka tentang hal yang berhubungan dengan orang banyak dengan batasan yang ada. Keterbukaan ini dapat dimulai dengan mencoba untuk saling berbagi keluh kesah yang kita rasakan dalam pekerjaan yang kita kerjakan dan bisa saja dengan kita saling berbagi tersebut kita juga sama sama untuk saling mensupport kegiatan yang sedang kita 
kerjakan. Apabila kita memiliki support dari lingkungan kita bukan tidak mungkin untuk kita semakin semangat dalam mengerjakan hal yang kita kerjakan tersebut. Dalam hal keterbukaan antara atasan dan pegawainya dapat kita lihat dengan keterbukaan laporan keuangan perusahaan atau yang sering disebut dengan transparansi laporan keuangan.

Penelitian ini menganalisis pentingnya transparansi laporan keuangan terhadap kinerja individu di dalam dunia kerja. Sehingga penelitian ini bertujuan untuk mengetahui apakah transparansi laporan keuangan mempengaruhi kinerja setiap individu yang terkait.

\section{Transparansi Laporan Keuangan}

Transparansi laporan keuangan berasal dari kata transparansi dan laporan keuangan dimana Menurut Didjaja (2003:261) transparansi merupakan keterbukaan pemerintah dalam membuat kebijakan- kebijakan sehingga dapat diketahui oleh masyarakat. Didjaja (2003:261) juga menyatakan bahwa transparansi meliputi lima hal sebagai berikut:

1. keterbukaan dalam rapat-rapat penting dimana masyarakat ikut memberikan pendapatnya

2. keterbukaan informasi yang berhubungan dengan dokumen yang perlu diketahui oleh masyarakat

3. keterbukaan prosedur

4. keterbukaan register yang berisi fakta hukum

5. keterbukaan menerima peran serta masyarakat.

Ministry Watch.com mengemukakan cara untuk mengetahui tingkat transparansi suatu organisasi dengan cara mengelompokkan transparansi ke dalam kategori low, medium, dan high.

Tabel 1. Tingkatan Transparansi

\begin{tabular}{|c|c|c|}
\hline $\begin{array}{c}1 \\
\text { Low }\end{array}$ & $\begin{array}{c}3 \\
\text { Medium }\end{array}$ & $\begin{array}{c}5 \\
\text { High }\end{array}$ \\
\hline $\begin{array}{l}\text { Organization failed to respond } \\
\text { positively to requests for } \\
\text { information (Organisasi gagal } \\
\text { merespons secara positif } \\
\text { permintaan informasi) }\end{array}$ & $\begin{array}{l}\text { Organization responded to part of } \\
\text { request or positively to all after } \\
\text { multiple follow- ups to the initial } \\
\text { request (Organisasi menanggapi } \\
\text { sebagian dari permintaan atau } \\
\text { secara positif terhadap semua } \\
\text { setelah beberapa kali } \\
\text { menindaklanjuti permintaan awal) }\end{array}$ & $\begin{array}{l}\text { Organization responded positivily } \\
\text { after no more than one follow-up } \\
\text { to the initial request (Organisasi } \\
\text { merespons secara positif setelah } \\
\text { tidak lebih dari satu tindak lanjut } \\
\text { terhadap permintaan awal) }\end{array}$ \\
\hline $\begin{array}{l}\text { Organization does not make } \\
\text { financial statements of any kind } \\
\text { available to the public (Organisasi } \\
\text { tidak membuat laporan keuangan } \\
\text { dalam bentuk apa pun tersedia } \\
\text { untuk umum) }\end{array}$ & $\begin{array}{l}\text { Organization makes minimal } \\
\text { useful financial information } \\
\text { available to the public (Organisasi } \\
\text { membuat informasi keuangan } \\
\text { yang berguna minimal tersedia } \\
\text { untuk publik) }\end{array}$ & $\begin{array}{l}\text { Organization makes numerous } \\
\text { quality financial statements } \\
\text { available to the public (Organisasi } \\
\text { membuat banyak laporan } \\
\text { keuangan berkualitas tersedia } \\
\text { untuk publik) }\end{array}$ \\
\hline
\end{tabular}

Sedangkan Baridwan (2004:17) mendefinisikan laporan keuangan merupakan ringkasan dari suatu proses pencatatan, merupakan suatu ringkasan dari taransaksi-transaksi keuangan yang terjadi selama tahun buku yang bersangkutan. Untuk tujuan laporan keuangan itu sendiri, Weygandt, et al. (2008: 58), FASB menyimpulkan bahwa tujuan- tujuan dari pelaporan keuangan adalah untuk menyediakan informasi yang: 1) Berguna bagi mereka yang membuat keputusan investasi dan kredit; 2) Membantu dalam memperkirakan arus kas di masa depan; dan 3) Mengidentifikasi sumber daya ekonomi (asset), klaim atas sumber daya tersebut (kewajiban) serta perubahan pada sumber daya dank laim tersebut. Menurut Ikatan Akuntan Indonesia (2009:3), tujuan laporan keuangan adalah menyediakan informasi yang menyangkut posisi keuangan, kinerja, serta perubahan posisi keuangan suatu perusahaan yang bermanfaat bagi sejumlah besar pemakai dalam pengambilan keputusan 
ekonomi. Dari pengertian para ahli maka dapat disimpulkan bahwa tujuan laporan keuangan sarana informasi untuk pemakai laporan keuangan tersebut yaitu seperti investor dan laporan ini sendiri menyediakan informasi terkait posisi keuangan perusahaan.

Dari pengertian dua kata tersebut, Widyaningsih (2010) mengatakan bahwa transparansi pelaporan keuangan adalah sebuah perilaku yang memberikan keterbukaan kepada seluruh pihak pihak yang berkepentingan, seperti masyarakat, pemegang saham, pengusaha, pemerintah dan seluruh pihak yang berkepentingan. Dapat disimpulkan juga bahwa transparansi laporan keuangan adalah keadaan dimana terciptanya keterbukaan yang ada pada sebuah perusahaan mengenai ringkasan dari informasi keuangan perusahaan tersebut kepada pihak-pihak yang membutuhkan dan dapat mempengaruhi keputusan yang akan diambil untuk kelangsungan hidup perusahaan tersebut. Dimagio dan Powell (2003) didalam teori pelaporan keuangan, Faktor yang mendorong munculnya transparansi laporan keuangan yaitu: 1) Pada saat mempublikasikan laporan keuangan secara transparan terdapat sejumlah variabel yang mempengaruhinya. Menurut Ridha dan Basuki (2012) terdapat beberapa variabel yang mempengaruhi transparansi laporan keuangan sebuah perusahaan; 2) Tranparansi dalam pelaksanaan pelaporan keuangan juga dapat terjadi karena adanya perubahan lingkungan, situasi genting tentu membuat setiap informasi didalam struktur keuangan pemerintah dilakukan dengan sebenarnya benarnya, seperti kasus Century yang mendorong seluruh pihak yang berkepentingan melakukan audit dengan proses yang sangat transparan, akan tetapi perubahan situasi bisnis atau lingkungan juga dapat menghambat transparansi, ketika segala norma dan aturan hukum tidak dijalankan dengan sebaik baiknya; dan 3) Pelaksanaan proses transparansi didalam pelaporan keuangan tentu akan muncul ketika seluruh anggota organisasi memiliki komitmen yang kuat untuk menjalankannya. Menurut Robbins dan Timothy (2008) komitmen menunjukan ungkapan janji yang akan dilaksanakan didalam sebuah organisasi, komitmen tentu akan terwujud ketika masing masing pihak didalam organisasi menjalankan perannya dengan baik.

\section{Kinerja}

Menurut pendekatan perilaku dalam manajemen, kinerja adalah kuantitas atau kualitas sesuatu yang dihasilkan atau jasa yang diberikan oleh seseorang yang melakukan pekerjaan (Luthans, 2005). (Rivai dan Basri, 2005) juga mengemukakan bahwa Kinerja adalah hasil atau tingkat keberhasilan seseorang secara keseluruhan selama periode tertentu dalam melaksanakan tugas dibandingkan dengan berbagai kemungkinan, seperti standar hasil kerja, target atau sasaran atau kriteria yang telah ditentukan terlebih dahulu telah disepakati bersama. Sehingga dapat disimpulkan bahwa kinerja adalah kualitas yang dihasilkan seorang individu ataupun kelompok yang dapat dinilai setelah individu atau sekelompok orang tersebut telah selesai melakukan suatu tugas atau pekerjaan.

Menurut Prawirosentono (1999) faktor-faktor yang mempengaruhi kinerja yaitu: 1) Efektifitas dan efisiensi yaitu bila suatu tujuan tertentu akhirnya bisa dicapai, kita boleh mengatakan bahwa kegiatan tersebut efektif tetapi apabila akibat-akibat yang tidak dicari kegiatan menilai yang penting dari hasil yang dicapai sehingga mengakibatkan kepuasan walaupun efektif dinamakan tidak efesien. Sebaliknya, bila akibat yang dicari-cari tidak penting atau remeh maka kegiatan tersebut efesien; 2) Otoritas (wewenang) menurut adalah sifat dari suatu komunikasi atau perintah dalam suatu organisasi formal yang dimiliki seorang anggota organisasi kepada anggota yang lain untuk melakukan suatu kegiatan kerja sesuai dengan kontribusinya. Perintah tersebut mengatakan apa yang boleh dilakukan dan yang tidak boleh dalam organisasi tersebut; 3) Disiplin adalah taat kepda hukum dan peraturan yang berlaku. Jadi, disiplin karyawan adalah kegiatan karyawan yang bersangkutan dalam menghormati perjanjian kerja dengan organisasi dimana dia bekerja; dan 4) Inisiatif yaitu berkaitan dengan daya pikir dan kreatifitas dalam membentuk ide untuk merencanakan sesuatu yang berkaitan dengan tujuan organisasi. 
John Miner mengemukakan 4 dimensi yang dapat dijadikan sebagai tolak ukur dalam menilai kinerja secara umum, yaitu (1)Kualitas, yaitu tingkat kesalahan, kerusakan, kecermatan, (2)Kuantitas, yaitu jumlah pekerjaan yang dihasilkan, (3)Penggunaan waktu dalam kerja, yaitu tingkat ketidakhadiran, keterlambatan, waktu kerja efektif/jam kerja hilang, (4)Kerja sama dengan orang lain dalam bekerja (Sudarmanto, 2009). Untuk mengetahui kinerja karyawan diperlukan kegiatan-kegiatan khusus. Bernandin dan Russell (2006) mengajukan enam kinerja primer yang dapat digunakan untuk mengukur kinerja, yaitu:

1. Quality, merupakan tingkat sejauh mana proses atau hasil pelaksanaan kegiatan mendekati kesempurnaan atau mendekati tujuan yang diharapkan.

2. Quantity, merupakan jumlah yang dihasilkan, misalnya jumlah rupiah, unit, siklus kegiatan yang dilakukan.

3. Timelinness, merupakan sejauh mana suatu kegiatan diselesaikan pada waktu yang dihendaki, dengan memperhatikan koordinasi output lain serta waktu yang tersebut untuk kegiatan orang lain.

4. Costeffectiveness, merupakan tingkat sejauh mana penggunaan sumber daya organisasi (manusia, keuangan, teknologi, dan material) dimaksimalkan untuk mencapai hasil tertinggi atau pengurangan kerugian dari setiap unit penggunaan sumber daya.

5. Need for supervision, merupakan tingkat sejauh mana seorang pekerja dapat melaksanakan suatu fungsi pekerjaan tanpa memerlukan pengawasan seseorang supervisor untuk mencegah tindakan yang kurang diinginkan.

6. Interpersonal impact, merupakan tingkat sejauh mana pegawai memelihara harga diri, nama baik, dan kerja sama diantara rekan kerja dan bawahan.

Menurut Simanjuntak dalam Widodo (2015:132) menyebutkan bahwa kinerja dipengaruhi oleh :

1. Kualitas dan kemampuan pegawai, yaitu hal-hal yang berhbungan dengan pendidikan/pelatihan, etos kerja, motivasi kerja, sikap mental, dan kondisi fisik pegawai.

2. Sarana pendukung, yaitu hal yang berhubungan dengan lingkungan kerja dan hal-hal yang berhubungan dengan kesejahteraan pegawai.

3. Supra sarana, yaitu hal-hal yang berhubungan dengan kebijaksanaan pemerintah dan hubungan industrial manajemen.

Tujuan dari diadakannya kegiatan untuk mengukur kinerja sudah dikemukakan oleh Sulistiyani dan Rosidah (2003 : 224), antara lain (1)Untuk mengetahui tujuan dan sasaran manajemen dan pegawai. (2)Memotivasi pegawai untuk memperbaiki kinerjanya. (3)Mendistribusikan reward dari organisasi atau instansi yang dapat berupa. (4)kenaikan pangkat dan promosi yang adil. (5)Mengadakan penelitian manajemen personalia. Sesuai dengan yang dikatakan oleh Munparidi, 2012, Berhasil atau tidaknya suatu perusahaan dalam menggapai tujuannya, tergantung oleh keberhasilan karyawan pada organisasi itu sendiri dalam melaksanakan tugas mereka. Berbagai macam halangan pasti akan ditemui oleh para individu organisasi untuk bisa bekerja dengan lebih baik sehingga kinerja mereka dapat diterima dengan baik oleh perusahaan ataupun masyarakat yang membutuhkan. Oleh karena itu dapat disimpulkan pula bahwa kinerja pegawai pada perusahaan sangat mempengaruhi kegiatan dari perusahaan tersebut dan oleh karenanya pula sebagai atasan kita harus tau bagaimana kinerja pegawai kita dalam waktu ke waktu agar kita tahu keputusan apa yang harus kita ambil setelahnya. Setiap organisasi mempunyai harapan yang besar agar pegawai dapat meningkatkan kinerja yang terbaik. Karena Kinerja merupakan unsurdari kesuksesan individu dalam melakukan suatu pekerjaan (Rochmad Fajar Darmanto, 2019).

Berdasarkan penelitian, Naharuddin dan Sadegi (2013) membuktikan kinerja karyawan tergantung pada kemauan dan juga keterbukaan karyawan itu sendiri dengan dirinya dan orang lain dalam melakukan pekerjaannya. Selanjutnya dia menyatakan adanya kemauan dan keterbukaan karyawan dalam menjalankan tugasnya, dapat meningkatkan produktivitas karyawan yang juga berujung pada kinerja.Untuk mencapai kinerja pegawai yang baik, tidak hanya individu pegawai 
tersebut saja yang harus diubah melainkan lingkungan kerja tersebut juga harus termasuk lingkungan kerja yang baik. Lingkungan kerja adalah segala sesuatu yang ada disekitar para pekerja yang dapat mempengaruhi dirinya dalam menjalankan tugas tugas yang dibebankan (Nela Pima Rahmawati, Bambang Swasto, 2014).

Lingkungan kerja sendiri terbagi menjadi dua macam, yaitu lingkungan kerja fisik dan lingkungan kerja nonfisik. Lingkungan kerja fisik merupakansemua keadaan berbentuk fisik yang terdapat disekitar tempat bekerja yang bisamemberikan pengaruh padakaryawan baik secara langsung maupun tidak langsung, sedangkan lingkungan kerja non fisik merupakansemua keadaan yang terjadidanberkaitan dengan hubungan kerja, baik hubungan kerja dengan atasan maupun hubungan sesama rekan kerja, ataupun hubungan dengan bawahan terciptanya lingkungan kerja yang nyaman, aman dan menyenangkan merupakan salah satu cara perusahaan untuk dapat meningkatkan kinerja para karyawan (Sedamaryanti 2011). Dengan lingkungan yang mendukung, bukan tidak mungkin bahwa kinerja pegwai yang bekerja akan senantiasa termotivasi untuk selalu bersemangat dalam mengerjakan tugasnya dan dengan hasil yang maksimal. Penelitian Raziq \& Maulabakhsh (2015) menyebutkan bahwa lingkungan kerja yang baik salah satunya meningkatkan produksi dan kinerja karyawan dimana pada akhirnya akan meningkatkan efektivitas organisasi serta dapat mengurangi biaya yang dikeluarkan oleh perusahaan.

\section{Hipotesis}

Hipotesis dari penelitian ini adalah anggapan penulis dengan masalah yang dikaji pada jurnal ini yaitu pentingnya transparansi laporan keuangan terhadap kinerja individu. Penulis berpendapatan bahwa transparansi mempengaruhi kinerja individu karena menurut penulis ketika terciptanya keterbukaan laporan keuangan akan lebih memudahkan dari segala pihak baim pihak atasan maupun pegawainya dalam bersikap dan mengambil keputusan yang dimana sikap dan keputusan tersebut akan mempengaruhi cara mencapai tujuan dari perusahaan tersebut didirikan.

\section{METODE}

Penelitian ini menggunakan metode penelitian kuantitaf. Metode penelitian kuantitatif adalah metode atau prosedur penelitian yang menghasilkan data deskriptif berupa kata- kata tertulis atau lisan dari orang-orang dan perilaku yang diamati (Suharsaputra, 2012). Data primer dari penelitian ini adalah berasal dari penyebaran kuisioner yang akhirnya diisi oleh 23 responden. Responden pada penelitian ini adalah para mahasiwa yang mengerti dan mempelajari mata kuliah Akuntansi.

Kuisioner yang sudah disediakan dan dibuat dengan google form lalu dikirim berupa link kepada para responden secara langsung dan hasilnya akan langsung ada pada google drive. Tenggat waktu yang ditentukan dalam pengisian kuisioner ini adalah selama 2 minggu. Sedangkan data sekunder pada penelitian ini adalah berasal dari jurnal-jurnal serta prosiding maupun tulisan lain yang berisi kajian teori sebagai dasar untuk memperkuat penelitian ini. Variabel pada penilitian ini adalah Transparansi Laporan Keuangan dan Seberapa Penting Laporan Keuangan terhadap Kinerja setiap Individu.

\section{HASIL DAN PEMBAHASAN}

\section{Hasil}

Terdapat 3(tiga) unsur pertanyaan yang ditanyakan melalui kuisioner yang dibagikan secara online dan diisi dengan 23 responden. Unsur pertama yang penulis teliti dari 23 responden kuisioner, yaitu apakah penting transparansi laporan keuangan bagi setiap individu. Berikut adalah hasil dari para responden. 


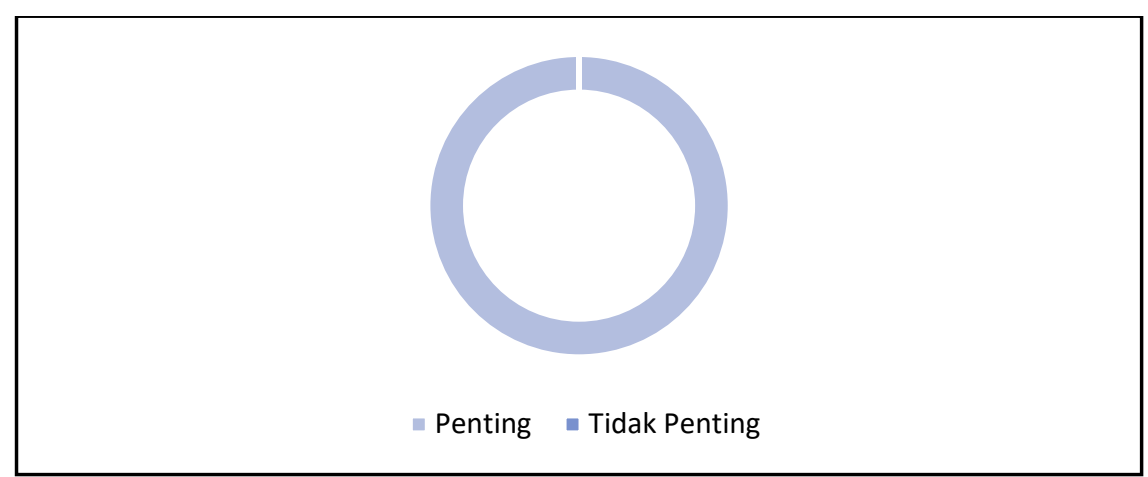

Diagram 1. Pentingnya Transparansi Laporan Keuangan

(Sumber : Dokumentasi Penelitian)

Unsur kedua yang penulis teliti adalah jenis transparansi laporan keuangan seperti apa yang dibutuhkan oleh setiap individu. Berikut adalah hasil dari para responden.

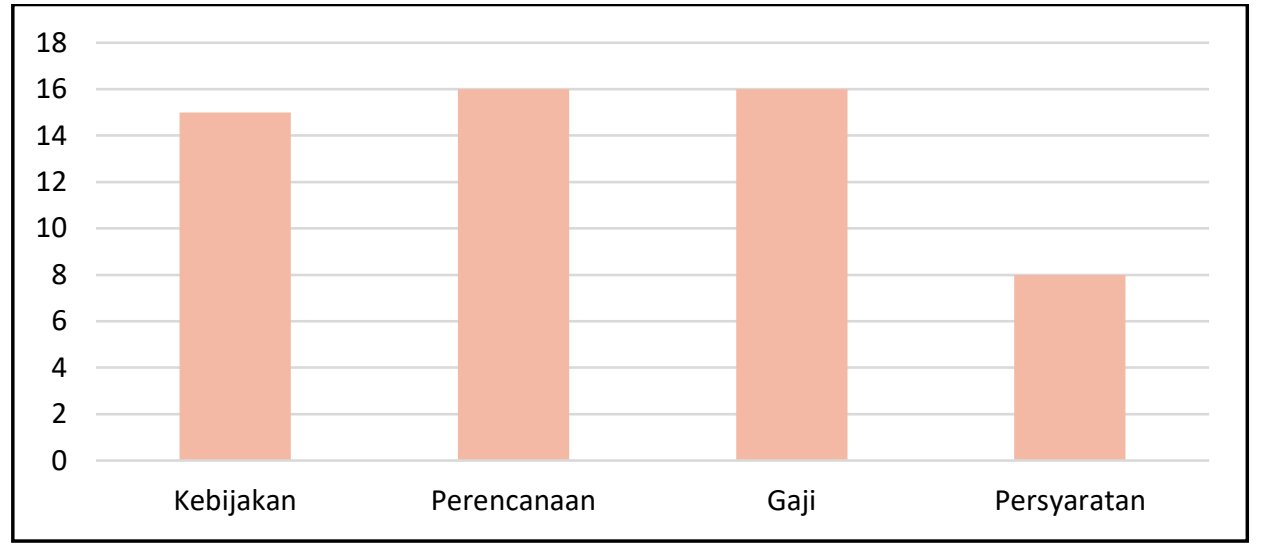

Grafik 2. Jenis Transparansi yang Dibutuhkan

(Sumber : Dokumentasi Penelitian)

Unsur terakhir yang penulis teliti adalah apakah transparansi laporan keuangan akan mempengaruhi kinerja karyawan pada perusahaan tersebut. Berikut adalah hasil dari para responden:

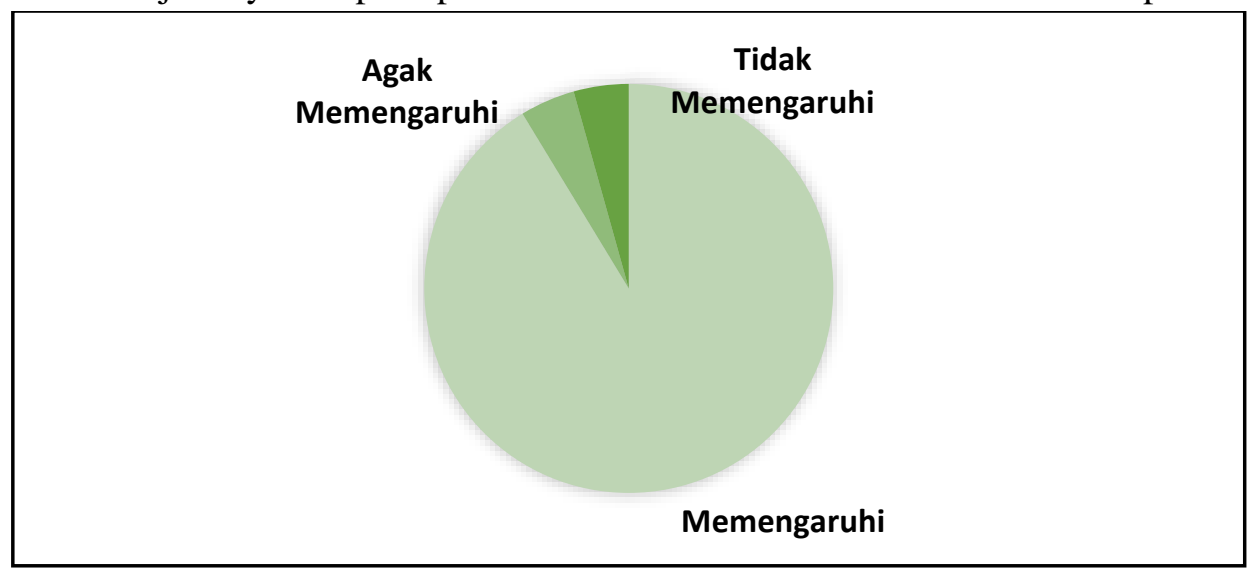

Grafik 3. Transparansi Memengaruhi Kinerja Karyawan

(Sumber : Dokumentasi Penelitian)

\section{Pembahasan}

Berdasarkan grafik 1 dapat diketahui bahwa 23 responden mengganggap bahwa transparansi laporan keuangan penting bagi setiap individu sehingga pada grafik tertulis $100 \%$ hasil yang muncul dalam jawaban penting. Transparansi yang berupa keterbukaan yang pada penelitian ini yaitu laporan keuangan sangatlah penting bagi setiap unsur-unsur yang ada pada sebuah perusahaan namun dengan batasan-batasan yang ada. Unsur-unsur yang membutuhkan dapat berupa investor, investor 
membutuhkan transparansi laporan keuangan agar investor tersebut tahu keputusan yang akan dia ambil yaitu apakah akan investai di perusahaan tersebut atau tidak. Selain itu, kreditur juga membutuhkan transparansi laporan keuangan karena dengan transparansi tersebut kreditur akan mengetahui kemampuan perusahaan dalam meminjam dana dan mengembalikan dana pada kreditur tersebut. Sehingga dapat disimpulkan bahwa transparansi laporan keuangan adalah hal yang sangat penting diketahui oleh setiap unsur yang berkaitan dalam perusahaan baik itu perusahaan pemerintah ataupun perusahaan swasta.

Berdasarkan grafik 2 dapat diketahui pula jenis jenis transparansi apa saja yang menurut responden penting bagi setiap individu. Dari hasil yang ditunjukkan terdapat 2 jenis transparansi yang paling penting ada dalam laporan keuangan yaitu, perencanaan dan gaji. Perencanaan adalah upayaupaya atau prose yang kita lakukan untuk mencapai tujuan dan cita-cita dari perusahaan tersebut. Aspek yang terkandung dalam perencanaan adalah perumusan tujuan dan cara mencapai tujuan tersebut dengan memanfaatkan sumber daya yang ada (Bastian, 2010:8). Perencanaan ini dapat digunakan bagi para pengguna laporan keuangan agar mereka tahu apa saja yang harus mereka capai dan kira-kira berapa banyak waktu yang mereka punya untyk mencapai tujuan tersebut. Perencanaan ini sangat penting diketahui karena apabila tidak, maka bisa saja para karyawan yang ada tidak tahu pa yang mereka akan capai dan mereka mungkin saja menunda-nunda pekerjaan mereka karena mengganggap tidak ada deadline yang harus mereka kejar. Sementara gaji, gaji adalah bayaran yang diterima setiap karyawan dari hasil jerih payah yang telah mereka lalui selama kurun waktu tertentu dan biasanya yang digunakan dalam perusahaan yaitu dalam kurun waktu sebulan. Gaji ini juga penting diketahui oleh masyarakat karena degan mereka mengetahui gaji pada perusahaan tersebut mereka akan mempertimbangkan apakah sepadan antara pekerjaan yang akan mereka kerjakan dengan bayaran atau gaji yang mereka dapatkan. Sementara bagi para karyawan selain mereka mengetahui kesepadanan kerja mereka, mereka akan tahu apakah gaji mereka akan segitu saja atau bisa meendapat tambahan disetiap periode tertentu. Penambahan gaji yang dimaksud adalah dapat berupa gaji lembur atau gaji yang mereka dapatkan dari achievement yang mereka dapatkan untuk membawa nama baik perusahaan. Gaji juga merupakan salah satu faktor yang mempengaruhi kinerja karyawan. Selain perencanaan dan gaji, 15 responde menjawab bahwa transparansi kebijakan laporan keuangan juga dibutuhkan bagi setiap individu. Kebijakan dapat dikatakan sebagai aturan yang ada pada perusahaan tempat mereka bekerja. Setiap perusahaan memiliki kebijakan yang bervariasi, oleh karenanya dibutuhkan transparansi kebijakan bagi pegawai yang bekerja pada perusahaan tersebut. Selain itu dengan keterbukaan kebijakan, bisa saja para pegawai meminta untuk merubah kebijakan yang ada apabila sudah tidak cocok dengan budaya yang ada pada perusahaan tersebut karena dengan kebijakan yang berlaku juga akan memengaruhi tercapainya cita-cita serta tujuan perusahaan tersebut. Yang terakhir yaitu transparansi laporan keuangan yang berupa persyaratan. Persayaratan ini akan dibutuhkan bagi para pencari kerja yang ingin melamar pekerjaan di perusahaan tempat bekerja itu karena ketika mereka mengetahui persyarata yang ada pada perusahaan tersebut, mereka akan menyiapkan apa saja yang harus disiapkan sebelum akhirnya mereka diterima bekerja di perusahaan yang mereka inginkan.

Berdasarkan grafik terakhir yaitu grafik 3 dapat kita lihat bahwa sebagian besar responden berpendapat bahwa transparansi laporan keuangan tersebut dapat memengaruhi kinerja karyawan yang ada pada perusahaan tersebut dan alasan terbanyak adalah dengan adanya transparansi ini para pegawai akan mengetahui bagaimana situasi perusahaan mereka sehingga mereka tahu bagaimana sikap yang akan mereka lakukan setelah mengetahuinya. Dapat dengan meningkatkan kinerja mereka, dapat juga meningkatkan efektifitas serta efisiensi yang ada pada perusahaan mereka. Ada juga yang berpendapat bahwa transparansi agak memengaruhi kinerja karyawan karena menurut mereka yang cukup tahu hanyalah orang orang yang berkepentingan saja. Selain itu, ada juga responden yang berpendapat bahwa transparansi ini tidak sama sekali memengaruhi kinerja karyawan. Dapat disimpulkan bahwa transparansi laporan keuangan dapat memengaruhi kinerja karyawan. 


\section{SIMPULAN}

Berdasarkan hasil penelitian yang dilakukan peneliti dapat diambil kesimpulan yaitu transparansi laporan keuangan adalah keadaan dimana terciptanya keterbukaan yang ada pada sebuah perusahaan mengenai ringkasan dari informasi keuangan perusahaan tersebut kepada pihak-pihak yang membutuhkan dan dapat mempengaruhi keputusan yang akan diambil untuk kelangsungan hidup perusahaan tersebut. Dari hasil penyebaran kuisioner dapat disimpulkan bahwa transparansi laporan keuangan adalah hal penting bagi setiap individu, jenis laporan keuangan tersebut dapat berupa laporan gaji dan perencanaan perusahaan. Transparansi laporan keuangan tersebut dapat mempengaruhi kinera karyawan karena dengan transparansi laporan keuangan para pegawai dapat memperbaiki kinerja mereka selama periode selanjutnya.

\section{Ucapan Terima Kasih}

Terimakasih penulis ucapkan kepada responden yang telah mengisi kuisioner yaitu kelas ABSP U4'2020 Politeknik STIALAN Bandung dan teman teman SMA Negeri 1 Tanjungpinang. Terimakasih juga untuk semua support yang telah diberikan sehingga jurnal ini dapat selesai.

\section{DAFTAR PUSTAKA}

Nurdarmasih, K., Atmadja. A. T., Julianto. I. P. (2019). Transparansi Dan Akuntabilitas Pengelolaan Keuangan Sistem Pemberian Kredit Mutranin Pada Dadia Tangkas Kori Agung Desa Pakraman Bila Bajang, Kecamatan Kubutambahan. Jurnal Ilmiah Mahasiswa Akuntansi,10(1), 3-4.

Riswan, Kesuma, Y. F. (2014). Analisi Laporan Keuangan Sebagai Dasar Dalam Penilaian Kinerja Keuangan PT. BUDI SATRIA WAHANA MOTOR. Jurnal Akuntansi \& Keuangan, 5(1), 2-3.

Utama, D. A., Setiyani, R. (2014). Pengaruh Transparansi, Akuntabilitas, dan Responsibilitas Pengelolaan Keuangan Sekolah Terhadap Kinerja Guru. Jurnal Pendidikan Ekonomi Dinamika Pendidikan, IX(2), 3-9.

Halmawati., Mustin, F. S. (2015). Penerapan Transparansi Pelaporan Keuangan Dalam Perspektif Tekanan Eksternal Dan Komitmen Organisasi. Book of Proceedings. (pp. 548, 551).

Khumaedi, E. (2016). Pengaruh Disiplin Dan Motivasi Kerja Terhadap Kinerja Pegawai Pada Dinas Sentra Operasi Terminal Pt. Angkasa Pura II. Jurnal Ilmiah Manajemen dan Bisnis,2(1)70-71.

Kristiana, A., Syaifulloh, M., Riono, S. B. (2020). Analisa Faktor-Faktor Yang Mempengaruhi Kinerja Karyawan Di RSU Islami Mutiara Bunda. Jurnal Manajemen dan Akuntansi, 16(1), 3-4.

Lestary, L., Harmon. (2017). Pengaruh Lingkungan Kerja Terhadap Kinerja Karyawan. Jurnal Riset Bisnis \& Investasi 3(2), 95. 